\title{
University of North Carolina School of Law
}

From the SelectedWorks of Andrew Chin

February 2, 2011

\section{Gene Probes as Unpatentable Printed Matter}

Andrew Chin 


\title{
GENE PROBES AS UNPATENTABLE PRINTED MATTER
}

\section{Andrew Chin ${ }^{*}$}

\begin{abstract}
In this Article, I argue that the most problematic kind of gene patents - those claiming short DNA molecules used to probe for longer gene sequences - should be held invalid as directed to unpatentable printed matter. This argument, which emerges from recent developments in biotechnology and information technology, is grounded in the printed matter doctrine's structural role of obviating patentability inquiries directed to inapposite information-management considerations. Where the inventive contribution in a claimed gene probe subsists solely in stored sequence information, these inapposite considerations lead the novelty and nonobviousness analyses to anomalous results that the printed matter doctrine was designed to avoid. I conclude that the doctrine should apply to all gene probes capable of being synthesized by known general methods.
\end{abstract}

* Associate Professor, University of North Carolina School of Law. I wish to thank Kevin Collins, Chris Holman, Jon Merz, Michael Risch, Joshua Sarnoff, and David Schwartz for invaluable and gracious comments; Shahid Khan and John Kivus for research assistance; and Keith Aoki, Adam Candeub, Yvonne Cripps, Johanna Dennis, Llewellyn Joseph Gibbons, Donna M. Gitter, and Jon Merz for signing the original version of the amicus brief on which this Article is based. All views expressed herein are solely my own. 


\section{INTRODUCTION}

So-called "gene patent" claims are often actually directed to gene probes. ${ }^{1}$ A gene probe is a short nucleic acid molecule (also known as an "oligonucleotide") that can be used to detect the presence of complementary sequences in a genetic sample. ${ }^{2}$ For example, two of the claims challenged by the American Civil Liberties Union and numerous public health organizations in the recent Myriad Genetics case ${ }^{3}$ cover any "isolated DNA having at least 15 nucleotides" of the DNA sequence encoding BRCA1, a protein associated with breast cancer, ${ }^{4}$ based on its utility as a gene probe in

${ }^{1}$ See Christopher M. Holman, The Impact of Human Gene Patents on Innovation and Access: A Survey of Human Gene Patent Litigation, 76 UMKC L. REV. 295, 313-14 (2007).

${ }^{2}$ See I. Edward Alcamo, Fundamentals of Microbiology 633 (2001).

3 Association for Molecular Pathology v. United States Patent \& Trademark Office, 702 F. Supp. 2d 181 (S.D.N.Y. 2010) [hereinafter Myriad]. Co-defendants Myriad Genetics and the University of Utah Research Foundation are the owners of the patents in suit. Id. at 184.

${ }^{4}$ U.S. Patent No. 5,747,282, claims 5-6 (issued May 5, 1998). 
various diagnostic procedures. $^{5}$

Like the patenting of genetic material more generally, ${ }^{6}$ the patenting of gene probes has been controversial. Appealing to the intimate connections between the human genome and the life, identity and shared heritage of the human species, some commentators have expressed ethical concerns over the commodification and propertization of parts of the human genome, concerns that extend to both full-length genes and gene probes. ${ }^{7}$ Other

${ }^{5}$ Id. at cols. 11-17.

${ }^{6}$ See generally Andrew Chin, Research in the Shadow of DNA Patents, 87 J. PATENT \& TRAdEMARK OfFICE SOC'y 846, 854-78 (2005) (surveying the controversy over gene patenting).

${ }^{7}$ See, e.g., Baruch Brody, Protecting Human Dignity and the Patenting of Human Genes, in A. Chapman, ed., Perspectives on Gene Patenting 111-26 (1999) (" $[\mathrm{I}] \mathrm{t}$ is wrong to commercialize something with which individuality and personhood is intertwined"); see also Mark J. Hanson, Biotechnology and Commodification Within Health Care, 24 J. MED. \& PHIL. 267 (1999) ("If the rhetoric regarding our genes becomes increasingly commodified at a time when media reports continue to strengthen the link between genes and human traits that centrally define us both as a species and as individuals, a subtle but not insignificant offense to notions of 
scholars have argued that the disclosures supporting gene probe patents provide the public with only preliminary characterizations of genetic sequences while precluding a broad range of downstream research on diagnostic and therapeutic techniques, ${ }^{8}$ as well as parallel research directed

personhood and concomitant self-perception may occur.”); Richard D. Land \& C. Ben Mitchell, Patenting Life: No, 63 First ThIngs 20, $20-22$ (1996) (condemning the patenting of genes as an illegitimate effort to claim that which can only be owned by God); U.S. Coalition Counters Breast Gene Patents, 381 NATURE 265 (1996) (reporting women's organizations' criticism that breast cancer gene probe patents deny women "control over the most intimate aspect of their being, their bodies' genetic blueprint.").

${ }^{8}$ See, e.g., Thomas Kiley, Patents on Random Complementary DNA Fragments, 257 SCIENCE 915 (1992) ("These patents cluster around the earliest imaginable observations on the long road toward practical benefit, while seeking to control what lies at the end of it."); Cara Koss, Note, Oysters \& Oligonucleotides: Concerns and Proposals for Patenting Research Tools, 25 CARDOZO ARTS \& ENT. L.J. 747, 754-58 \& n.67 (2007) (describing the granting of oligonucleotide patents of dubious utility); Cynthia D. Lopez-Beverage, Should Congress Do Something About Upstream Clogging Caused By the Deficient Utility of Expressed Sequence 
toward identifying other patentable gene probes. ${ }^{9}$ Concerns over the development of a research anticommons ${ }^{10}$ have led to some notable defensive publication efforts, including the Merck Gene Index and the SNP

Tag Patents?, 10 J. TECH. L. \& POL'Y 35, 76-85 (2005) (describing the poor quality and preclusive effects of gene fragment patents); John F. Merz et al., Diagnostic Testing Fails the Test, 415 NATURE 577 (2002); American College of Medical Genetics, Position Statement on Gene Patents and Accessibility of Gene Testing (visited June 6, 2002) 〈http://www.faseb.org/genetics/acmg/pol-34.htm〉 ("[R]estricting the availability of gene testing ... retards the usually very rapid improvement of a test that occurs through the addition of new mutations or the use of new techniques by numerous laboratories that have accumulated samples from affected individuals over many years.").

${ }^{9}$ See Chin, supra note 6, at 895 (showing how "existing patents on oligonucleotides might impair the future search for patentable DNA molecules, including other oligonucleotides").

${ }^{10}$ See Michael A. Heller \& Rebecca S. Eisenberg, Can Patents Deter Innovation? The Anticommons in Biomedical Research, 280 SCIENCE 698, 698-99 (1998). 
Consortium. ${ }^{11}$ More recently, critics of gene patents have taken aim at the doctrinal distinction between patented isolated and purified nucleic acids and unpatentable genetic materials occurring in nature, ${ }^{12}$ finding a

11 See Andrew Chin, Artful Prior Art and the Quality of DNA Patents, 57 ALA. L. REV. 975, 1016-18 (2006).

12 See John M. Conley, Gene Patents and the Product of Nature Doctrine, 84 CHI.-KenT L. REV. 109 (2009); John M. Conley \& Roberte Makowski, Back to the Future: Rethinking the Product of Nature Doctrine as a Barrier to Biotechnology Patents, 85 J. PAT. \& TRADEMARK OfF. SoC'Y 301 (2003); Linda J. Demaine \& Aaron Xavier Fellmeth, Reinventing the Double Helix: A Novel and Nonobvious Reconceptualization of the Biotechnology Patent, 55 STAN. L. REV. 303, 407-10 (2002) (arguing that isolation and purification of DNA molecules would not pass the authors' proposed "substantial transformation" test). 
sympathetic ear in the district court in Myriad. ${ }^{13}$ None of these arguments, however, has yet persuaded the Federal Circuit or the Patent Office. ${ }^{14}$

Patent claims directed to short DNA molecules raise particular concerns about overbreadth because they typically cover all possible longer sequences that include the claimed subsequence. ${ }^{15}$ In principle, such claims should also be the most vulnerable to anticipation. General methods of synthesizing oligonucleotides have been widely known and used since at

13 See Myriad, 702 F. Supp. 2d at 185 (citing Conley \& Makowski, supra note 10); id. at 232 (concluding that "the claimed isolated DNA is not markedly different from native DNA as it exists in nature" and therefore unpatentable).

${ }^{14}$ See Chin, supra note 6, at 868-70 \& 873-78 (discussing the Federal Circuit's and Patent Office's responses to criticisms of gene patenting).

15 See Jasemine C. Chambers, Update on USPTO Practice: Tips for Biotech Patent Prosecution, in Biotechnology LAw 2005, 840 PLI/Pat 7, 23-24 (2005) (explaining that a claim to an oligonucleotide "comprising at least a portion" of a recited nucleotide sequence "contemplates additional nucleotides"); Holman, supra note 1, at 314 ("In a practical sense, these claims to probes and sequence fragments can provide more expansive patent coverage than claims directed to the full-length gene sequence."). 
least the 1980 s. ${ }^{16}$ As I demonstrated in a previous article ${ }^{17}$ and the Federal Circuit confirmed in In re Gleave, ${ }^{18}$ any prior art reference describing these methods and listing any of the claimed oligonucleotide sequences would anticipate and invalidate these claims under $\S 102(\mathrm{~b})$. It is trivial to computer-generate and publish a list of all oligonucleotide sequences of a given length, provided that such a list can be stored feasibly on a medium that can be made accessible to the public. ${ }^{19}$ Thus the novelty of DNA oligonucleotide claims hinges largely on whether structural definitions of the claimed sequences have previously been typed out as A's, C's, G's and T's in such a computer-generated list and published. Such a consideration has more to do with the norms of the scientific community regarding scholarly communication and with the availability of low-cost, highcapacity information storage media, than with the state of the art in biotechnology. ${ }^{20}$

${ }^{16}$ See infra note 76.

${ }^{17}$ See Chin, supra note 11.

18560 F.3d 1331 (Fed. Cir. 2009).

${ }^{19}$ See Chin, supra note 11 , at 1009-10.

${ }^{20}$ See id. at 1021-23. 
This Article argues that the patentability analysis of DNA oligonucleotide claims should not reach these irrelevant considerations, because DNA oligonucleotides capable of being synthesized by known general methods should be held ineligible for patenting under patent law's printed matter doctrine. The printed matter doctrine serves to pre-empt inapposite analyses of differences between the claimed invention and the prior art - e.g., analyses focused on the management of stored information rather than on the field of invention — that would otherwise be applied under the novelty doctrine of $\S 102$ or the nonobviousness doctrine of $\S 103$.

As I will argue, the printed matter doctrine is applicable to DNA oligonucleotide molecules because they are disposed to store nucleotide sequence information in a manner analogous in all relevant respects to other substrates that may be more intuitively recognizable as information storage media, such as laser-printed text on paper. Moreover, to the extent that a hybridization reaction involving a claimed oligonucleotide is recognized as having specific and substantial utility, it is by virtue of the semantic properties that scientists have attached to the complementary DNA sequence, not an inventive functional relationship between the sequence information and its molecular substrate. While hybridization reactions involving the claimed oligonucleotide probes may impart new and 
unobvious information regarding cancer, such information is useful and intelligible only to the human mind and cannot confer patentability.

This Article opens a new front in the gene patenting debate. Until I filed the Myriad amicus brief in the Federal Circuit on which this Article is based, ${ }^{21}$ no one had ever challenged the validity of a gene patent on the ground that it was directed to printed matter. ${ }^{22}$ While it is widely recognized that DNA is "information embedded in a substrate of molecules" and that "it is the informational content of a DNA molecule that differentiates it from the prior art of other DNA molecules,"23 opponents of gene patents have appealed to these characterizations only for the purpose of arguing that genetic information is a phenomenon of nature. ${ }^{24}$ Such

21 Brief of Amici Curiae Scholars of Biotechnology Patent Law in Support of Plaintiffs-Appellees, Supporting Affirmance, Association for Molecular Pathology v. U.S. Patent \& Trademark Office, No. 2010-1406 (Fed. Cir. filed Dec. 7, 2010), available at http://andrewchin.com/chin/outreach/myriadamicus.pdf.

22 See Kevin E. Collins, Semiotics 101: Taking the Printed Matter Doctrine Seriously, 85 IND. L.J. 1379, 1389 n. 40 (2010).

${ }^{23}$ See id. at 1389.

${ }^{24}$ See, e.g., Myriad, 702 F. Supp. 2d at 194 (finding that "[G]enes and 
arguments have tended to conflate claimed DNA molecules with the sequence information they contain, an approach the patent system has vigorously rejected. $^{25}$ In this Article, I share the view that DNA's

the information represented by human gene sequences are products of nature universally present in each individual"); U.S. Patent \& Trademark Office, Utility Examination Guidelines, 66 Fed. Reg. 1092, 1093 (Jan. 5, 2001) [hereinafter "Utility Guidelines"] (summarizing public comments to the effect that "the sequence of the human genome is at the core of what it means to be human and no person should be able to own/control something so basic" or obtain patents "for discoveries in nature"); Bita Amani, Patents, the Charter \& A Healthy Dose of Rights in Wrongs: The Poison is the Elixir for Life, Liberty \& Security of the Person, 57 U.N.B. L.J. 162 (arguing that "genes are information" and are "our endowment from nature; they are not invented"); Debra Greenfield, Intangible or Embodied Information: The Non-Statutory Nature of Human Genetic Material, 25 Santa Clara Computer \& High TeCH. L.J. 467, 536 (2009) (arguing that the law of nature exclusion should preclude the granting of patents "on the exclusive use of genetic information").

25 See Utility Guidelines, supra note 24, at 1093-94 (Jan. 5, 2001) (acknowledging that "descriptive sequence information alone is not 
informational content is significant for patentability, but argue that it is an insight more properly addressed to the printed matter doctrine than to the product of nature exclusion.

\section{DESCRIPTION AND PURPose OF THE PRINTED MATTER DOCTRINE}

\section{A. The Doctrine's Broad Applicability}

The printed matter doctrine states that "“[m]ere printed matter can not impart a patentable feature to a claim.",26 The doctrine does not apply, however, when there is a "new and unobvious functional relationship between the printed matter and the substrate." 27

patentable subject matter" but explaining that a patent claim may be directed to "a new and useful purified and isolated DNA compound described by the sequence").

${ }^{26}$ In re Gulack, 703 F.2d 1381, 1385 (Fed. Cir. 1983) (quoting In re Miller, 418 F.2d 1392 (C.C.P.A.1969)).

27703 F.2d at 1386. 
As Judge Linn explained in In re Nuijten, ${ }^{28}$ the printed matter doctrine precludes patentability where the differences between the claimed invention and the prior art subsist merely in stored information:

Under the "printed matter" doctrine, if the only distinction between a prior art storage medium and a claimed storage medium is the information stored thereon - rather than a different "functional relationship between the printed matter and the substrate" — then the claimed storage medium (with associated information) is unpatentably obvious over the prior art because the information lacks "patentable weight.,"29

The printed matter doctrine has survived the progression of printing technologies from typewriters and treadle presses to laser printers and nanolithography without having been limited to any particular kind of storage medium. ${ }^{30}$ Instead, it extends to any physical substrate capable of holding information, subject to the "functional relationship" limitation noted above. Accordingly, courts over the years have proceeded to apply

\footnotetext{
28500 F.3d 1346 (Fed. Cir. 2007).

${ }^{29} I d$. at 1365 (Linn, J., concurring-in-part and dissenting-in-part).

${ }^{30}$ See id.
} 
the doctrine and its accompanying limitation in cases involving a wide range of substrates. ${ }^{31}$

\section{B. The Doctrine's Structural Role}

The printed matter doctrine has traditionally been viewed as an elaboration of the $\S 101$ patentable subject matter requirement. ${ }^{32}$ The

31 See, e.g., In re Bryan, 323 Fed.Appx. 898 (Fed. Cir. 2009) (unpublished) (game boards); In re Gulack, 703 F.2d 1381 (Fed. Cir. 1983) (paper, fabric or plastic bands); In re Miller, 418 F.2d 1392 (C.C.P.A.1969) (measuring cups and spoons); Ex parte Gwinn, 112 U.S.P.Q. 439 (B.P.A.I 1955) (dice in a "parlor golf game"); In re Kothny, 96 F.2d 289 (C.C.P.A. 1938) (scales for measuring cylindrical records); In re McKee, 75 F.2d 991 (C.C.P.A. 1935) (meat products); In re Johns, 70 F.2d 913 (C.C.P.A. 1934) (animal carcasses); In re Sterling, 70 F.2d 910 (C.C.P.A. 1934) (checkbooks); Cincinnati Traction Co. v. Pope, 210 F. 443 (6th Cir. 1913) (trolley transfer tickets).

32 See 1 Chisum on PATENTs $§ 1.02[4]$, at 1-24 (2006) (““[P]rinted matter' by itself did not constitute a 'manufacture",); see also Examination Guidelines for Computer-Related Inventions, 61 Fed. Reg. 7478, 7481 (Feb. 
doctrine's reliance on "patentable weight" considerations, however, is more akin to a Graham analysis of the nonobviousness of the "differences between the prior art and the claims at issue,"33 than the "claim as a whole" approach that pervades modern patentable subject matter doctrine. ${ }^{34}$ Accordingly, the printed matter doctrine has also sometimes been applied as part of a $\S 102$ or $\S 103$ analysis. $^{35}$ Despite the ambiguous location of its statutory basis, the printed matter doctrine has survived to the present day. ${ }^{36}$

As the Federal Circuit recently explained in King Pharmaceuticals, Inc. v. Eon Labs. ${ }^{37}$ the rationale behind the printed matter cases is "preventing the indefinite patenting of known products by the simple inclusion of novel,

28, 1996) (instructing examiners to reject non-functional descriptive material under $\S 101)$.

${ }^{33}$ Graham v. John Deere Co., 383 U.S. 1, 17-18 (1966).

${ }^{34}$ See Diamond v. Diehr, 450 U.S. 175, 189-91 (1981).

${ }^{35}$ See, e.g., In re Ngai, 367 F.3d 1336 (Fed. Cir. 2004); In re Gulack, 703 F.2d 1381 (Fed. Cir. 1983); see also In re Nuijten, 500 F.3d 1346, 1365

(Fed. Cir. 2007) (Linn, J., concurring-in-part and dissenting-in-part) (characterizing the doctrine as supporting a conclusion of obviousness).

${ }^{36}$ See infra section II.C.

${ }^{37} 616$ F.3d 1267 (Fed. Cir. 2010). 
yet functionally unrelated limitations." ${ }^{, 38}$ The printed matter doctrine guards against the diversion of patentability analysis into assessments of the novelty and nonobviousness of information fixed in, but not conferring new and nonobvious functionality upon, the underlying substrate.

In so doing, the printed matter doctrine serves alongside the judicially created exceptions to patentable subject matter to pre-empt inapposite analyses of differences between the claimed invention and the prior art that would otherwise be applied under the novelty doctrine of $\S 102$ and/or the nonobviousness doctrine of $\S 103 .{ }^{39}$ Courts do not inquire into the nonobviousness of newly discovered natural principles, because "the discovery of some of the handiwork of nature ... is not patentable ... however ingenious the discovery of that natural principle may have been."40 Similarly, where "the only distinction between a prior art storage medium and a claimed storage medium is the information stored thereon,"

${ }^{38}$ Id. at 1279.

${ }^{39} C f$. Collins, supra note 22, at 1387 (explaining that the doctrine in effect "excludes certain useful and nonobvious products of human ingenuity from the patent regime").

${ }^{40}$ Funk Bros. Seed Co. v. Kalo Inoculant Co., 333 U.S. 127, 131 (1948).

${ }^{41}$ In re Nuijten, 500 F.3d at 1365. 
Graham analysis of the nonobviousness of the "differences between the prior art and the claims at issue" would entail inquiries into the nonobviousness of the stored information relative to prior art stored information and the level of ordinary skill in information recombination, regardless of the field of the underlying invention. ${ }^{42}$

Courts have consistently regarded such information-management considerations as inapposite to the assessment of inventive contributions in the relevant field of endeavor. For example, In re Russell ${ }^{43}$ dealt with a directory in which surnames were arranged phonetically. The applicant argued that his invention comprised "finished tangible subject matter bearing specifically arranged data or means, combined to produce a novel result."44 The court affirmed the Patent Office's rejection, holding: "The mere arrangement of printed matter on a sheet or sheets of paper, in book form or otherwise, does not constitute 'any new and useful art, machine, manufacture or composition of matter." $" 45$ This expression of the printed matter doctrine served to obviate an irrelevant inquiry into the novelty and

\footnotetext{
${ }^{42}$ See Graham v. John Deere Co., 383 U.S. at 17-18.

${ }^{43} 48$ F.2d 668 (C.C.P.A. 1931).

${ }^{44}$ Id. at 668 .

${ }^{45}$ Id. at 669.
} 
nonobviousness of the applicant's "finished tangible" directory as an information source relative to prior art directory and phonetic information sources.

Similarly, in Guthrie v. Curlett $^{46}$ the patentee asserted a claim to a "consolidated tariff index" that compiled the shipping rates set by numerous transportation companies, using a system of symbols to facilitate a compact presentation. $^{47}$ The court credited the patentee with showing "how to compress into small space a lot of information about freight tariffs," but explained that the proper subject of the patentability inquiry was the "means ... for making a consolidated index. ${ }^{\text {48 }}$ Finding the disclosed means to consist solely of the non-novel "employment of symbols," the court concluded that the claim was directed to unpatentable subject matter. ${ }^{49}$ The court thereby refrained from an inapposite inquiry into the ability of one skilled in the art to combine and compress the information from prior art individual tariff schedules into a single compact document.

\footnotetext{
46 10 F.2d 725 (2d Cir. 1926).

${ }^{47}$ Id. at 725 .

${ }^{48}$ Id. at 726.

${ }^{49} I d$.
} 
In In re $\mathrm{Ngai}^{50}$ the applicant invented a new procedure for normalizing and amplifying RNA using a known reagent. ${ }^{51}$ The Patent Office allowed his method claims, but rejected a claim directed to a kit combining the reagent with instructions for performing the new procedure. ${ }^{52}$ The Federal Circuit affirmed the rejection under the printed matter doctrine, finding that the claimed invention amounted to "the addition of new printed matter to a known product" with no functional relationship between the two: "Here the printed matter in no way depends on the kit, and the kit does not depend on the printed matter. All that the printed matter does is teach a new use for an existing product.... If we were to adopt [applicant's] position, anyone could continue patenting a product indefinitely provided that they add a new instruction sheet to the product." 53 The court's application of the printed matter doctrine thereby avoided a Graham inquiry as to whether one of ordinary skill would have been able to assemble the claimed kit from the prior art - a task that would entail producing and storing instructions for a

\footnotetext{
50367 F.3d 1336 (Fed. Cir. 2004).

${ }^{51}$ Id. at 1337.

${ }^{52}$ Id. at $1337-38$.

${ }^{53}$ Id. at $1338-39$.
} 
new and nonobvious procedure. ${ }^{54}$

Patent law's novelty and nonobviousness doctrines are particularly illsuited to fact-specific assessments of the inventiveness embodied in stored information, because these doctrines artificially construct the knowledge of the person having ordinary skill in the art as including all publicly accessible information resources, no matter how obscure. ${ }^{55}$ By obviating an analysis directed to stylized facts and inapposite information-management considerations, the printed matter doctrine preserves the integrity of the novelty and nonobviousness doctrines as promoters of progress in the useful arts.

${ }^{54}$ See id. at 1338 (noting applicant's attempt to distinguish the kit claim by "argu[ing] that ... prior art does not teach a limitation of 'instructions describing the method of [the method claim], combined with an amplification kit").

55 See, e.g., In re Hall, 781 F.2d 897 (Fed. Cir. 1986) (finding that "a single cataloged thesis in one university library" was sufficiently accessible to one exercising reasonable diligence to constitute a $\S 102(\mathrm{~b})$ "printed publication"). 


\section{The Doctrine's Continuing Operation}

The printed matter doctrine is a long-established principle of patent law that survived the enactment of the 1952 Patent Act. ${ }^{56}$ While there is some ambiguity today as to which section of the 1952 Act supplies its statutory basis, ${ }^{57}$ the doctrine has never been repudiated in over a century. ${ }^{58}$

In particular, the Supreme Court's recent decision in Bilski v. Kappos ${ }^{59}$ did not disturb the printed matter doctrine, not least because the doctrine

${ }^{56}$ See, e.g., In re Miller, 418 F.2d 1392 (C.C.P.A. 1969); In re Russell, 42 F.2d 668 (C.C.P.A. 1931); U.S. Credit System Co. v. Am. Credit Indemnity Co., 59 F. 139, 143 (2d Cir. 1893); see generally Harold C. Wegner, The Disclosure Requirements of the 1952 Patent Act: Looking Back and a New Statute for the Next Fifty Years, 37 AKRON L. REV. 243, 243 (2004) ("The great bulk [of the 1952 Act] was a mere codification of principles, going back in some cases to the earliest patent laws of the eighteenth century ....”).

57 See supra section II.B,

${ }^{58}$ See, e.g., In re Ngai, 367 F.3d 1336 (Fed. Cir. 2004).

59130 S.Ct. 3218 (June 28, 2010). 
does not arise solely in connection with claims to $\S 101$ "process[es]."60 Moreover, none of the Court's reasoning in Bilski affects the operation of the printed matter doctrine.

As discussed in Section II.B, the printed matter doctrine's functional role in preempting inapposite analyses of differences between the claimed invention and the prior art is essentially complementary to that of the judicially created exceptions to patentable subject matter affirmed in Bilski and Diehr. Thus, even though the Supreme Court in these decisions has required an "invention as a whole" approach to $§ 101$ patent-eligible subject matter analysis, ${ }^{61}$ this requirement has not affected the printed matter doctrine's reliance on "patentable weight" considerations, as the post-Diehr decisions of the Federal Circuit show. ${ }^{62}$ Since Bilski, the court has continued to treat the printed matter doctrine as operative and relevant to patentability analysis. ${ }^{63}$

${ }^{60}$ See CHISUM, supra (““[P]rinted matter’ by itself did not constitute a 'manufacture"').

${ }^{61}$ See Bilski, 130 S.Ct. at 3230 (citing Diehr, 450 U.S. at 188),

${ }^{62}$ See, e.g., In re Ngai, 367 F.3d 1336 (Fed. Cir. 2004).

63 See King Pharmaceuticals, Inc. v. Eon Labs, Inc., 616 F.3d 1267, 1278-79 (Fed. Cir. Aug. 2, 2010) (citing printed matter cases as persuasive 
The Bilski Court clarified that the only exceptions to patentable subject matter supported by the Court's precedents are for laws of nature, physical phenomena, and abstract ideas, ${ }^{64}$ definitively retiring the idea of a categorical exclusion for business methods. ${ }^{65}$ The printed matter doctrine's precedential support, however, is in no way undermined by the Court's repudiation of the supposed "business method" exception. While it may be observed that the printed matter doctrine originated in part from cases involving printed business forms, ${ }^{66}$ the applicability of the doctrine has never been limited to business methods. ${ }^{67}$ Moreover, since the early business-form cases, the role of the printed matter doctrine has developed independently of any putative justification for excluding the category of business methods from patentability. ${ }^{68}$

authority for point-of-novelty analysis of method claim).

$$
\begin{aligned}
& { }^{64} 130 \text { S.Ct. at } 3226 . \\
& { }^{65} \text { Id. at } 3228 . \\
& { }^{66} \text { See, e.g., Hotel Security Checking Co. v. Lorraine, } 160 \text { F. } 467 \text { (2d }
\end{aligned}
$$

Cir. 1908); United States Credit System Co. v. American Credit Indemnity Co., 59 F. 139 (2d Cir. 1893).

$$
\begin{aligned}
& { }^{67} \text { See, e.g., In re Ngai, } 367 \text { F.3d } 1336 \text { (Fed. Cir. 2004). } \\
& { }^{68} \text { See, e.g., In re Nuijten, } 500 \text { F.3d 1346, } 1365 \text { (Fed. Cir. 2007) (Linn, }
\end{aligned}
$$


In summary, the printed matter doctrine continues to serve alongside other judicial exclusions, fulfilling an important role in maintaining the integrity of patentability doctrine where novelty and nonobviousness inquiries would improperly be directed at the content, form and management of stored information rather than the functionality conferred by the information upon the underlying substrate.

\section{Oligonucleotides Under the PRINTED MATTER DOCTRINE}

\section{A. Locus of the Inventive Contribution}

J., concurring-in-part and dissenting-in-part) (describing the printed matter doctrine as "potentially more apposite as a consequence of the 'useful' requirement of $\S 101 ”) ;$ Boggs v. Robertson, 13 U.S.P.Q. 214, 214 (D.C. Sup. Ct. 1931) (applying the doctrine as an extension of the abstract ideas exception); see also supra Section II.B (describing the doctrine's complementary role to the exceptions for laws of nature, physical phenomena, and abstract ideas); Collins, supra note 22, at 1402 (arguing that the abstract ideas exception "comes the closest to a source of support for the doctrine"). 
The synthesis and use of isolated DNA oligonucleotides as hybridization probes has been known in the published literature since at least $1975 .^{69}$ Oligonucleotides as gene probes differ from the oligonucleotides used in prior art hybridization probe procedures only with respect to the nucleotide sequences carried thereon. ${ }^{70}$ Thus, the inventive contributions of the claimed oligonucleotide compositions subsist merely in the nucleotide sequence information stored in the claimed molecules. ${ }^{71}$

By structure and function, DNA oligonucleotides are disposed to store nucleotide sequence information in a manner analogous in all relevant respects to other substrates that may be more intuitively recognizable as

${ }^{69}$ See Edwin Mellor Southern, Detection of Specific Sequences Among DNA Fragments Separated by Gel Electrophoresis, 98 J. MoLECULAR BIOLOGY 503 (1975).

${ }^{70}$ See, e.g., U.S. Patent No. 5,198,338, col. 3 (issued May 30, 1993) (describing the use of Southern hybridization with isolated DNA olignoucleotide probes "of a suitable hybridizable length (generally longer than 15 nucleotides)" for the detection of T-cell malignancy).

${ }^{71}$ See Collins, supra note 22, at 1390 ("The difference between a newly isolated and purified strand of DNA and prior art DNA molecules resides in the content of the DNA-as-information. .."). 
information storage media. ${ }^{72}$ Structurally, characters comprising textual information are physically represented on a laser-printed page by defined patterns of toner powder fused to a paper surface. ${ }^{73}$ Similarly, nucleotide sequence information is physically represented in the DNA molecule by four defined types of submolecular units called "bases," wherein each base is bonded to a 5-carbon sugar that has a phosphate group attached to form a

72 Admittedly, all chemical structures carry structural information. See Dan L. Burk, The Problem of Process in Biotechnology, 43 Hous. L. REV. 561, 583-84 (2006) ("Due to its size, DNA can carry a very large amount of structural information, but this structural encoding is similarly the case for all biological macromolecules and indeed is at some greater or lesser degree true of all chemical structures."); Collins, supra note 22, at 1389 n.44 (noting that it would be "a conceptual error to frame DNA as unique in raising the question of whether molecules are information with content"). Significantly, however, gene probes are the subjects of such routine methods of synthesis and use that any inventive contributions necessarily reside in the sequence information itself.

73 See Laser Printer, WIKIPEDIA <http://en.wikipedia.org/wiki/ Laser_printer> (accessed Nov. 28, 2010). 
sequential unit called a "nucleotide."74 The resulting structure in each case physically manifests the specific information stored in the substrate, thereby enabling that information to be retrieved.

Functionally, laser printing stores textual information on a paper substrate through a computer-automated procedure that sequences and controls the process of placing and fusing the toner powder onto the page. ${ }^{75}$ Analogously, automated oligonucleotide synthesis stores nucleotide sequence information in a DNA molecule through a computer-automated procedure that sequences and controls the process of placing and binding nucleotides onto the molecule, which is covalently bonded to a solid support. $^{76}$ The user of an oligonucleotide synthesizer merely has to type in

${ }^{74}$ See In re O’Farrell, 853 F.2d 894, 896 (Fed. Cir. 1988).

${ }^{75}$ See Laser Printer, supra.

76 Oligonucleotide synthesis dates back to the early 1950s, soon after the discovery of the structure of DNA. See Daniel M. Brown, A Brief History of Oligonucleotide Synthesis, in 20 Protocols FOR OligonuCleotides And AnAlogs 1, 1 (1993). Phosphotriester technology for oligonucleotide synthesis was primarily developed in the 1960s and 1970s and refined and popularized in the 1980s. See Brown, supra, at 7-9; see also Keiichi Itakura et al., Synthesis and Use of Synthetic 
the sequence and "press[] a few buttons.",77 Nucleotide sequence information can subsequently be retrieved from a DNA oligonucleotide using modern sequencing procedures. ${ }^{78}$

While the fixation of nucleotide sequence information in the DNA

Oligonucleotides, 53 ANN. REV. BIOCHEMISTRY 323, 353 (1984) (“[T]he chemical synthesis of oligodeoxyribonucleotides has become a routine laboratory procedure.”). In phosphotriester synthesis, the most widely used methodology, there are four steps in each nucleotide addition, and at each step appropriate compounds are added and washed out as the reaction proceeds. The four steps are: (1) de-blocking of the DMT group on the last nucleotide added, (2) coupling to the next nucleotide, (3) capping against any unreacted nucleotides, and (4) oxidation of the linkage to render it stable. See Oligonucleotide Synthesis, WIKIPEDIA <http://en.wikipedia.org/wiki/Oligonucleotide_synthesis\#Synthetic_cycle> (visited Nov. 28, 2010).

${ }^{77}$ See Richard Pon, Solid-Phase Supports for Oligonucleotide Synthesis, in 20 PRotocols For OligonuCleOtides AND ANALOGS 465, 465 (1993).

${ }^{78}$ See Enzo Biochem, Inc. v. Gen-Probe, Inc., 323 F.3d 956 (Fed. Cir. 2002) (finding that one of ordinary skill can use known sequencing techniques to obtain nucleotide sequences from deposited DNA molecules). 
molecule occurs on an intramolecular level, the microscopic scale of this phenomenon does not belie the fact that DNA oligonucleotides are analogous in structure and function to other physical substrates that store and manifest information as printed matter, such as laser-printed paper. Any structural differences between the claimed oligonucleotide compositions and prior art DNA oligonucleotides are simply the physical manifestation of differences in nucleotide sequence information as it is stored in the respective molecular substrates. Under the printed matter doctrine, therefore, any inventive contributions of the claimed oligonucleotide contributions should be found to subsist merely in stored information.

\section{B. Inapposite Patentability Inquiries}

As explained in section II.B supra, the printed matter doctrine serves to pre-empt the diversion of patent law's novelty and nonobviousness analyses into information-management considerations unrelated to progress in the field of the underlying invention. The analysis of the patentability of oligonucleotide probes is uniquely susceptible to such diversion, because of two interrelated facts. First, as the Federal Circuit has recently explicitly recognized, general methods of making isolated DNA oligonucleotides of 
arbitrary sequence have long been well known. ${ }^{79}$ Second, large databases providing nucleotide sequence information, but not listing all oligonucleotide subsequences thereof, have been available to the public since the early 1980 s. $^{80}$

At least until recently, the Federal Circuit has characterized both of these facts as largely irrelevant to the novelty and nonobviousness analyses of claims to particular isolated DNA oligonucleotides. In In re Deuel, ${ }^{81}$ the court held that the availability of general methods of making isolated DNA molecules "is essentially irrelevant to the question whether the specific [claimed] molecules themselves would have been obvious" to one of

${ }^{79}$ See In re Gleave, 560 F.3d 1331, 1336 (Fed. Cir. 2009) (finding prior art to be enabling based on applicant's admission that "it is well within the skill of an ordinary person in the art to make any oligodeoxynucleotide sequence"); Brown, supra note 76.

80 See GenBank, WIKIPEDIA< http://en.wikipedia.org/ wiki/GenBank\#History> (visited Nov. 28, 2010); David S. Roos, Bioinformatics: Trying to Swim in a Sea of Data, 291 SCIENCE 1260 (2001) (noting GenBank "continues to more than double in size every year").

${ }^{81} 51$ F.3d 1552 (Fed. Cir. 1995). 
ordinary skill. ${ }^{82}$ Databases of nucleotide sequences, without more, typically do not anticipate claims to isolated oligonucleotides comprising specific subsequences thereof, because such databases usually do not teach all limitations of an isolated oligonucleotide claim, e.g., by listing the sequence of every such oligonucleotide. ${ }^{83}$

Gleave implies that the patentability analysis of claimed DNA oligonucleotides would be very different if scientists were in the practice of publishing lists of oligonucleotide subsequences in addition to the fulllength sequences from which they were derived. In Gleave, the Federal Circuit reviewed the Patent Office's rejection of a claim to an antisense DNA oligonucleotide substantially complementary to genes encoding two types of insulin-dependent growth factor binding protein. ${ }^{84}$ The examiner imposed, and the Board approved, a $§ 102(\mathrm{~b})$ rejection over a reference that

${ }^{82}$ Id. at 1559; but see In re Kubin, 561 F.3d 1351, 1358-59 (Fed. Cir. 2009) (noting the Supreme Court's repudiation of Deuel to the extent that Deuel foreclosed arguments that a combination of elements was "obvious to try").

${ }^{83}$ See generally In re Gleave, 560 F.3d at 1336-38 (discussing different treatment of lists and genera under anticipation case law).

${ }^{84} I d$. 
listed each of the more than 1400 fifteen-base-long sense oligonucleotides contained in one of the genes and suggested making antisense oligonucleotides capable of interacting with the listed sense oligonucleotides. ${ }^{85}$ Noting that "a person of ordinary skill in the art equipped with an IGFBP sequence is admittedly capable of envisioning how to make any antisense sequence," the court found the reference to anticipate all of the listed sense oligonucleotides and their antisense counterparts. $^{86}$

That the proliferation of nucleotide sequences in public databases has not been accompanied by equally extensive and particularized documentation of oligonucleotide sequences does not reflect limitations in the state of the art in biotechnology, but norms in scholarly communication. Given any long nucleotide sequence, it is a trivial matter to identify all of the oligonucleotides of a given length contained therein; to list all of them would contribute nothing to the advancement of science and be a frivolous waste of space. It is not surprising that the lengthy oligonucleotide listing cited as prior art in Gleave was from a patent application rather than a

\footnotetext{
${ }^{85}$ Id. at $1333-34$.

${ }^{86}$ Id. at 1338.
} 
professional scientific publication. ${ }^{87}$

It is an equally trivial (though scientifically uninteresting) matter to list all oligonucleotide sequences of a given length that can be made with known synthesis techniques, and thereby to generate a defensive publication that anticipates a broad class of oligonucleotide compositions. As I demonstrated in a previous article, ${ }^{88}$ the potential impact of such defensive publications on the patentability of oligonucleotides is limited only by the capacity of digital storage media. ${ }^{89}$

In March 2002, I prepared a text document entitled "On the Preparation and Utilization of Isolated and Purified Oligonucleotides," containing (1) a technical explanation of how to make and use isolated and purified oligonucleotides of arbitrary sequence (derived from the presumably enabling specifications of previously issued patents), and (2) a computergenerated list of 11 million nucleotide sequences 8 to 12 bases in length that could be made and used by the disclosed methods. ${ }^{90}$ This document was recorded on CD-ROM and deposited in the University of North Carolina

\footnotetext{
${ }^{87}$ Id. at 1333.

${ }^{88}$ See Chin, supra note 11.

${ }^{89}$ See id. at 1021-23.

${ }^{90}$ See id. at 1036-38 \& n. 410.
} 
School of Law's library, where it was indexed, cataloged and shelved under the Library of Congress subject heading for oligonucleotides on March 14, 2002..$^{91}$ This "shotgun reference" has been effective $\S 102(\mathrm{~b})$ prior art against oligonucleotide composition claims filed on or after March 15, 2003.92

${ }^{91}$ See id. at 1010.

${ }^{92}$ See 35 U.S.C. $§ 102(b)$.

As of October 15, 2010, the CD-ROM has been cited in the prosecution history of 39 issued patents, including 35 whose applications originally contained oligonucleotide composition claims. See U.S. Patents Nos. 6946267, 6953669, 7049067, 7087733, 7090980, 7098192, 7105319, 7108973, 7132233, 7166430, 7176181, 7186537, 7198898, 7229976, 7291725, 7339041, 7342109, 7345161, 7393641, 7393950, 7407943, 7414033, 7416725, 7468431, 7495094, 7514241, 7553618, 7589190, 7618947, 7622455, 7678895, 7700574, 7709628, 7718628, 7732590, 7737264, 7759318, 7759479. In all 35 cases, the oligonucleotide composition claims were either canceled or narrowed by amendment to exclude sequences of 8 to 12 bases in length. In one case, the patent examiner also cited the reference in a $\S 103$ rejection of several method claims. See U.S. Patent No. 7090980 (final rejection of Oct. 14, 2005). 


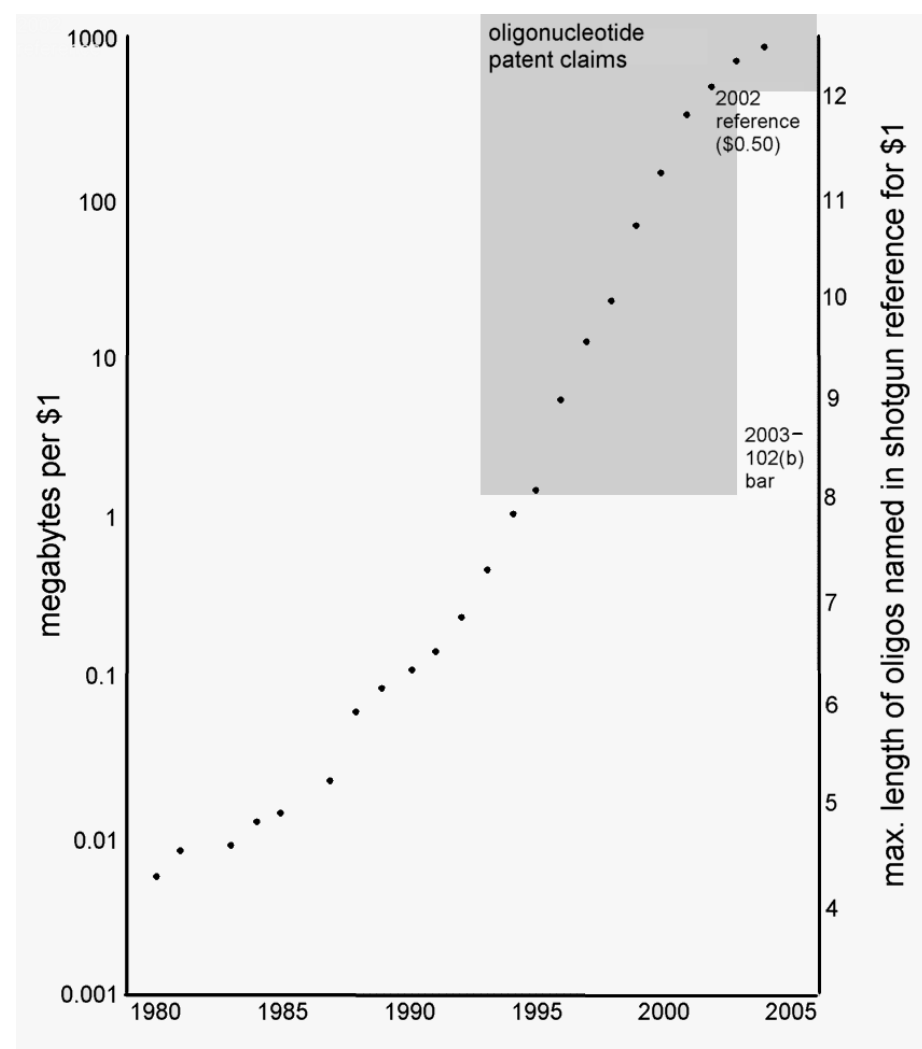

Fig. 1. Impact of the CD-ROM reference on patentability of oligonucleotides. $^{93}$

The "shotgun reference" was limited to 11 million sequences only by the capacity of a CD-ROM in 2002. As Fig. 1 illustrates, at any given time, the feasibility of producing a shotgun reference as effective prior art against oligonucleotides of a given length is dependent on the availability of highcapacity, low-cost digital media. In Fig. 1, the impact of the CD-ROM

${ }^{93}$ Chin, supra note 11 , at 1022. 
reference is represented by the white segment that has been carved out of the shaded rectangle; the right scale indicates that as of 2003, broad claims to oligonucleotides of 8 to 12 bases were no longer patentable. As the data points plotted against the left scale illustrate, continuing advances in information storage technology may be expected to make it feasible to generate and publish shotgun references covering oligonucleotides of everincreasing lengths.

There is a deep incongruity in these results. Known methods of synthesizing arbitrary isolated DNA oligonucleotides represent a significant part of the state of the art in biotechnology. ${ }^{94}$ In contrast, the existence (or nonexistence) of shotgun references listing the sequences of arbitrary isolated oligonucleotides is of no significance to the state of the art in biotechnology. The feasibility of generating and publishing a shotgun reference of a given scope is determined solely by the state of information storage technology. Yet patent doctrine holds that such a sequence listing anticipates an oligonucleotide composition claim, ${ }^{95}$ while oligonucleotide synthesizers do not even render such a claim obvious. ${ }^{96}$

\footnotetext{
${ }^{94}$ See Brown, supra note 76.

${ }^{95}$ See Gleave, 560 F.3d at 1336-38.

${ }^{96}$ See Deuel, 51 F.3d at 1559.
} 
The CD-ROM reference (and the patent system's response thereto) concretely demonstrates that the novelty and nonobviousness analyses of oligonucleotide composition claims are deeply and inextricably contingent on information-management considerations that are irrelevant to the state of the art in biotechnology. The printed matter doctrine can serve its functional role by obviating such analyses. ${ }^{97}$

\section{The Information-Substrate Relationship}

"Additional advantageous activity" may distinguish a claimed species as nonobvious over a known genus. ${ }^{98}$ While the specific utility of oligonucleotides in testing for longer, clinically significant genetic sequences may represent "additional advantageous activity" in which nonobviousness subsists, this utility is not the result of a "new and unobvious functional relationship between the printed matter and the substrate." 99 Accordingly, the printed matter doctrine should be applied to invalidate gene probe claims.

\footnotetext{
${ }^{97}$ See section II.B.

${ }^{98}$ See In re Albrecht, 514 F.2d 1389 (C.C.P.A. 1975).

${ }^{99}$ In re Gulack, 703 F.2d at 1386.
} 
In Gulack, the claimed invention was an endless band on which had been printed the first $P-1$ significant digits in the repeating decimal expansion of $1 / P$, where $P$ is a prime number. ${ }^{100}$ This number has the property that cyclic shifts of the digits produce integer multiples of the original number. ${ }^{101}$ The inventor claimed the band as "an educational and recreational mathematical device" that would display cyclic shifts of the original number, whose multiplicative properties might be used, inter alia, "to perform magic tricks or to display various aspects of number theory."102 The specification and claims included such embodiments as a belt, hatband, necklace, or ring. ${ }^{103}$

The examiner rejected several claims under the printed matter doctrine, and the Board affirmed, finding "no functional relationship of the printed material to the substrate." 104 The court reversed, finding that "the digits of

${ }^{100}$ See id. at 1383.

101 See id. For example, the decimal expansion of $1 / 7$ is $.142857142857 \ldots$ A cyclic shift of the number 142857 has the property that $428571=3 * 142857$.

${ }^{102}$ See id.

${ }^{103}$ See id.

${ }^{104}$ See id. at 1384. 
Gulack's invention are functionally related to the band."105 The court reasoned:

The appealed claims, on the other hand, require a particular sequence of digits to be displayed on the outside surface of a band. These digits are related to the band in two ways: (1) the band supports the digits; and (2) there is an endless sequence of digits - each digit residing in a unique position with respect to every other digit in an endless loop. Thus, the digits exploit the endless nature of the band. ${ }^{106}$

Crucial to the court's analysis was its finding that "there is an endless sequence of digits" that could not have been stored on anything other than a distinctive kind of substrate; i.e., one with an "endless nature." Gulack's specification, however, teaches that "the sequence of digits imprinted on the band" is the finite sequence of $P-1$ digits described above. ${ }^{107}$ The Gulack court thus appears to have construed "the digits of Gulack's invention" as intrinsically incorporating a special mathematical property that could be manifested only by also including all cyclic shifts of those digits.

${ }^{105} I d$. at 1385 .

${ }^{106}$ Id. at $1386-87$.

${ }^{107}$ See id. at 1383. 
In contrast, the nucleotide sequences of the claimed oligonucleotide compositions do not possess any intrinsic property that necessitates a distinctive kind of substrate. An oligonucleotide synthesizer fixes the sequence information of the claimed oligonucleotides into the substructures of a DNA molecule in the same way as it processes any other sequence information. $^{108}$

It may be argued that oligonucleotides manifest higher-order structures that dispose them to hybridize specifically with clinically significant complementary DNA sequences. From a functional standpoint, however, the causal disposition of oligonucleotides to hybridize with complementary DNA sequences - the only causal disposition that the oligonucleotides of a typical gene probe claim have in $\operatorname{common}^{109}$ - is common to all

${ }^{108}$ See supra note 76.

109 The universe of oligonucleotides is structurally diverse, see, e.g., M.A. Viswamitra, Structural Diversity in DNA: From Monomer Structures to Oligonucleotides, 47 COLD SPRING HARBOR SyMP. QuANTITATIVE BIOLOGY 25 (1983). Typical gene probe claims are broad enough to cover a diverse group of oligonucleotides, i.e., by using the open transitional term "comprising" and covering all sufficiently long subsequences of a recited longer sequence. See Chambers, supra note 15. Because of this diversity, 
oligonucleotides, and is neither new nor unobvious. ${ }^{110}$ The sequence information of a group of claimed oligonucleotides possesses no intrinsic property that distinguishes the functional properties of their underlying substrates from those of other oligonucleotides.

such claims can ensure a common causal property only by picking out precisely those oligonucleotides that hybridize with a specified DNA sequence.

In contrast to oligonucleotides, longer DNA molecules that encode proteins with metabolic functions may have both meaning that is semantic and information content that is non-semantic, see Peter Godfrey-Smith, Genes Do Not Code for Phenotypic Traits, in CONTEMPORARY DEBATES IN PHILOSOPHY OF SCIENCE 275, 281-94 (Christopher Hitchcock ed. 2004), and therefore might not be covered by the printed matter doctrine. $C f$. In re Fisher, 421 F.3d 1365, 1373 (Fed. Cir. 2005) (finding expressed sequence tags that were "unable to provide any information about the overall structure let alone the function of the underlying [protein-encoding] gene" to lack patentable utility as research tools).

${ }^{110}$ See In re Deuel, 51 F.3d at 1554-55 (explaining that DNA probes "exploit the fact that the bases in DNA always hybridize in complementary pairs"). 
To the extent that a hybridization reaction involving a claimed oligonucleotide is recognized as having specific utility, it is by virtue of the semantic properties that scientists have attached to the complementary DNA sequence, not a new and unobvious functional relationship between the sequence information and the molecular substrate. ${ }^{111}$ While hybridization reactions involving the claimed oligonucleotide probes may impart new and unobvious information regarding cancer, such information is "useful and intelligible only to the human mind" and cannot confer patentability. ${ }^{112}$

111 See U.S. Patent No. 5,747,282, col. 7 (describing the observation of "large extended families ... with multiple cases of breast cancer" to support scientists' inferences regarding the locus of the BRCA1 gene); see also Godfrey-Smith, supra note 109, at 283 (arguing that apart from protein synthesis, causal claims linking genes and phenotypic traits are grounded in semantic description).

112 See In re Lowry, 32 F.3d 1579 (Fed. Cir. 1994) (citing In re Bernhart, 417 F.2d 1395, 1399 (C.C.P.A. 1969)) ("The printed matter cases 'dealt with claims defining as the invention certain novel arrangements of printed lines or characters, useful and intelligible only to the human mind."); see also Collins, supra note 22, at 1383 ("Standing alone, newly invented semiotic meanings are not eligible for patent protection. Similarly, 
CONCLUSION

This is admittedly an unusual argument. The courts have not previously applied the printed matter doctrine to preclude the patenting of DNA molecules. ${ }^{113}$ It has only been relatively recently, however, that unrelated but contemporaneous developments in biotechnology and information technology have thrown the doctrinal incongruity described above into high relief. It is only a matter of time until information technology supports the publication of shotgun references that foreclose the patenting of oligonucleotides of any given length. The courts can declare an end to this irrelevant waiting game by holding that the printed matter doctrine precludes the patenting of oligonucleotides capable of being synthesized by known general methods.

attaching new semiotic meanings to old worldly things does not make the worldly things patentable.”).

113 See Collins, supra note 22, at 1389 n. 40 (noting that "printed matter challenges have not been brought against gene patents"). 